\title{
Indoor radon concentrations in workplaces and dwellings in North-Western Greece
}

\author{
K. loannides, D. Patiris and C. Papachristodoulou \\ Department of Physics, University of Ioannina, 45110 loannina, Greece
}

\begin{abstract}
Measurements of indoor radon concentrations were performed in 44 workplaces and 87 dwellings in the region of Epirus, north-western Greece, using electret and alpha-track detectors. Radon concentrations followed a log-normal distribution with an arithmetic mean of $(92 \pm 54) \mathrm{Bq} \mathrm{m}^{-3}$ in workplaces and $(86 \pm 52) \mathrm{Bq} \mathrm{m}^{-3}$ in dwellings. In all cases, radon levels were below $400 \mathrm{~Bq} \mathrm{~m}^{-3}$, which is the action level proposed by the European Commission. Comparing summer and winter measurements, no statistically significant seasonal variation was established. However, radon concentrations measured in basement and ground floor levels were significantly higher $(\mathrm{p}<0.001)$ than those measured in the first and upper floors. A mean annual effective dose of 0.64 and $1.63 \mathrm{mSv} \mathrm{y}^{-1}$ was estimated for occupational and residential exposure, respectively. The reported data contribute to the assessment of radon distribution and dose estimate at the national level.
\end{abstract}

\section{INTRODUCTION}

Radon and its decay products are significant natural sources of radiation exposure for the general population, both in the living and working environment. Thus, over the last decades, surveys of indoor radon are continuously performed worldwide. In Greece, a nationwide indoor radon mapping is still lacking, although several small-scale studies in dwellings have been published. The more comprehensive survey has been carried out from 1995 to 1998, including data from more than 1000 dwellings, mainly located in the eastern and southern country [1]. A recent pilot study reported radon concentrations in 561 workplaces in 19 prefectures covering north-eastern Greece [2].

In this work, radon measurements were performed in typical workplaces and dwellings in Ioannina, which is a major city with a municipal population of approximately 75,000 (2001 census), located in the region of Epirus, north-western Greece. The area has not been included in large-scale surveys of indoor radon and only fragmentary data appear in literature (see Fig. 1). The reported results aim at contributing to the assessment of radon distribution and dose estimate at the national level.

\section{EXPERIMENTAL}

Electret Ionization Chambers of the "H"-type (E-PERM, Rad Elec Inc., USA) were used for passive radon measurements in 44 public workplaces, situated in the University, the University Hospital and the Ioannina Prefecture Administration buildings. In all workplaces, the E-PERM chambers were installed during both summer (May-July) and winter (November-January) periods and exposed for 8-10 days.

Radon measurements were performed during summer (May-September) and winter (October-April), in 87 randomly selected dwellings in the area of Ioannina, using CR-39 solid state nuclear track detectors (Pershore Moulding Ltd., UK). The experimental setup, etching protocol, track counting and calibration procedures have been described elsewhere [3, 4].

\section{RESULTS}

\subsection{Radon concentrations in workplaces}

Radon concentrations in workplaces follow a log-normal distribution ( $\mathrm{p}<0.05$ ), as shown in Fig. 2 a. Descriptive statistics are listed in Table 1. The results fall within the range reported in a recent pilot 
study carried out in 561 workplaces in other parts of the country [2]. All radon concentration values were found to be below $400 \mathrm{~Bq} \mathrm{~m}^{-3}$, which is the action level implemented for workplaces by the Greek Radiation Protection Regulations, following the EC recommendation [5].

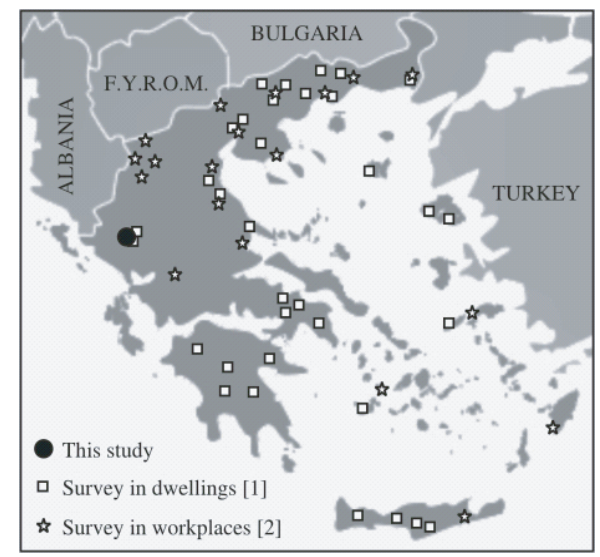

Figure 1. A map showing the sampling location of the present study. The area has scarcely been included in previous investigations of indoor radon.

Summer and winter measurements were compared through a paired student's t-test and no statistically significant seasonal variation was established $(p=0.298)$. However, one-way analysis of variance (ANOVA) followed by Fisher's LSD post hoc test, showed that radon concentrations measured in basement and ground floor workplaces were significantly higher than those measured in the first and upper floors (see Fig. 2b).

\subsection{Radon in dwellings}

Radon concentrations in dwellings are log-normally distributed and range between 11 and $286 \mathrm{~Bq} \mathrm{~m}^{-3}$ with an arithmetic mean of $92 \mathrm{~Bq} \mathrm{~m}^{-3}$ (see Fig. 3a and Table 2). All values were below $400 \mathrm{~Bq} \mathrm{~m}^{-3}$ and only in two basement dwellings did values exceed $200 \mathrm{~Bq} \mathrm{~m}^{-3}$, which are the action levels applying to existing buildings and future constructions, respectively [8]. No statistically significant variations were found between summer and winter radon levels and between radon levels measured in detached house and apartment dwellings. A significant variation with floor level was established, with mean radon concentrations decreasing from basement to upper floors (see Fig. 3b).

Previous measurements from 18 dwellings in Ioannina [1], yielded radon concentrations ranging from 26 to $600 \mathrm{~Bq} \mathrm{~m}^{-3}$ with an arithmetic mean of $89 \mathrm{~Bq} \mathrm{~m}^{-3}$. An older investigation [9] conducted in 55 dwellings in the town of Metsovo, situated in Ioannina prefecture, revealed higher radon concentrations ranging from 18 to $750 \mathrm{~Bq} \mathrm{~m}^{-3}$ with an arithmetic mean of $170 \pm 132 \mathrm{~Bq} \mathrm{~m}^{-3}$.

\subsection{Dose estimation}

The annual mean effective dose $\mathrm{H}\left(\mathrm{mSv}^{-1}\right)$ from radon and its decay products was calculated according to UNSCEAR [6], through the equation:

$$
\mathrm{H}=\mathrm{C} \times \mathrm{E} \times \mathrm{F} \times \mathrm{T} \times \mathrm{D},
$$


where $\mathrm{C}$ is radon concentration $\left(\mathrm{Bq} \mathrm{m}^{-3}\right), \mathrm{E}$ is the equilibrium factor between radon and its decay products $(=0.4 ;[7]), \mathrm{F}$ is the occupancy factor, $T=8760 \mathrm{~h} \mathrm{y}^{-1}$ and $\mathrm{D}$ is the dose conversion factor $\left(9 \times 10^{-6} \mathrm{mSv}\right.$ per Bq m$\left.{ }^{-3} ;[7]\right)$.

Using the mean value of $92 \mathrm{~Bq} \mathrm{~m}^{-3}$ for radon concentration in workplaces and assuming an occupancy factor of 0.22 (i.e. working for $1920 \mathrm{~h}$ per y), the annual mean effective dose was estimated to be $0.64 \mathrm{mSv} \mathrm{y}^{-1}$. Those working in offices located on basement and ground floors attain the higher risk (see Table 3). It should be noted that these estimates are based on short term measurements that may not accurately reflect radon levels throughout the year.

The annual mean effective dose from residential radon exposure was estimated to be $1.63 \mathrm{mSv} \mathrm{y}^{-1}$, assuming an occupancy factor of 0.6 . This value is close to the worldwide average of $1.15 \mathrm{mSv} \mathrm{y}^{-1}$ reported by UNSCEAR [6] for the dose due to inhalation of radon decay products. On a national basis, annual effective doses between 0.09 and $28 \mathrm{mSv}^{-1}$ have been determined [1].

Table 1. Results from the present work and from a study in workplaces from other parts of Greece. $\mathrm{N}=$ number of workplaces, $\mathrm{AM}=$ arithmetic mean, $\mathrm{SD}=$ standard deviation from the mean, $\mathrm{GM}=$ geometric mean.

\begin{tabular}{|c|c|c|c|c|c|}
\hline & $\mathrm{N}$ & $\begin{array}{c}\mathrm{AM} \pm \mathrm{SD} \\
\left(\mathrm{Bq} \mathrm{m}^{-3}\right)\end{array}$ & $\begin{array}{c}\mathrm{GM} \\
\left(\mathrm{Bq} \mathrm{m}^{-3}\right)\end{array}$ & $\begin{array}{c}\text { Range } \\
\left(\mathrm{Bq} \mathrm{m}^{-3}\right)\end{array}$ & $>400 \mathrm{~Bq} \mathrm{~m}^{-3}$ \\
\hline This work & 44 & $92 \pm 54$ & 79 & $21-278$ & - \\
\hline Summer & 44 & $85 \pm 46$ & 74 & $21-229$ & - \\
\hline Winter & 44 & $98 \pm 59$ & 83 & $27-278$ & - \\
\hline Ref [2] & 561 & 123 & 106 & $29-695$ & $5(0.9 \%)$ \\
\hline
\end{tabular}

Table 2. Summary statistics for radon concentrations measured in dwellings in the region of Epirus. $\mathrm{N}=$ number of dwellings, $\mathrm{AM}=$ arithmetic mean, $\mathrm{SD}=$ standard deviation from the mean, $\mathrm{GM}=$ geometric mean.

\begin{tabular}{|c|c|c|c|c|c|}
\hline & $\mathrm{N}$ & $\begin{array}{c}\mathrm{AM} \pm \mathrm{SD} \\
\left(\mathrm{Bq} \mathrm{m}^{-3}\right)\end{array}$ & $\begin{array}{c}\mathrm{GM} \\
\left(\mathrm{Bq} \mathrm{m}^{-3}\right)\end{array}$ & $\begin{array}{c}\text { Range } \\
\left(\mathrm{Bq} \mathrm{m}^{-3}\right)\end{array}$ & $>200 \mathrm{~Bq} \mathrm{~m}^{-3}$ \\
\hline This work & 87 & $86 \pm 52$ & 72 & $11-286$ & $2(2.3 \%)$ \\
\hline Detached & 31 & $83 \pm 68$ & 61 & $11-286$ & $2(6.4 \%)$ \\
\hline Apartment & 56 & $87 \pm 42$ & 78 & $32-190$ & - \\
\hline Ref [1] & 18 & 89 & 60 & $26-600$ & $1(5.6 \%)$ \\
\hline Ref [9] & 55 & $170 \pm 132$ & 146 & $18-750$ & $5(0.9 \%)$ \\
\hline
\end{tabular}

Table 3. Effective doses estimated in workplaces and dwellings, broken down by floor level. B = basement; $\mathrm{G}=$ ground floor; 1 = first floor; $>1=$ above first floor.

\begin{tabular}{|c|c|c|c|c|c|}
\hline & $\begin{array}{l}\text { Floor } \\
\text { level }\end{array}$ & $\mathrm{N}$ & $\mathrm{AM}\left(\mathrm{Bq} \mathrm{m}^{-3}\right)$ & $\begin{array}{l}\text { Occupancy } \\
\text { factor }\end{array}$ & $\begin{array}{l}\text { Effective dose } \\
\left(\mathrm{mSv}^{-1}\right)\end{array}$ \\
\hline \multirow{3}{*}{ Workplaces } & all & 44 & 92 & 0.22 & 0.64 \\
\hline & $\mathrm{B} ; \mathrm{G}$ & 19 & 130 & & 0.90 \\
\hline & $1 ;>1$ & 25 & 63 & & 0.44 \\
\hline \multirow[t]{4}{*}{ Dwellings } & $\begin{array}{ll}\text { all } \\
\end{array}$ & 87 & 86 & 0.60 & 1.64 \\
\hline & $\mathrm{B}$ & 8 & 174 & & 3.31 \\
\hline & $\mathrm{G}$ & 31 & 95 & & 1.81 \\
\hline & $1 ;>1$ & 48 & 64 & & 1.22 \\
\hline
\end{tabular}

\section{CONCLUSIONS}

In the present study, radon concentrations were monitored in workplaces and dwellings in the area of Ioannina, in north-western Greece. This part of the country has scarcely been investigated for indoor 

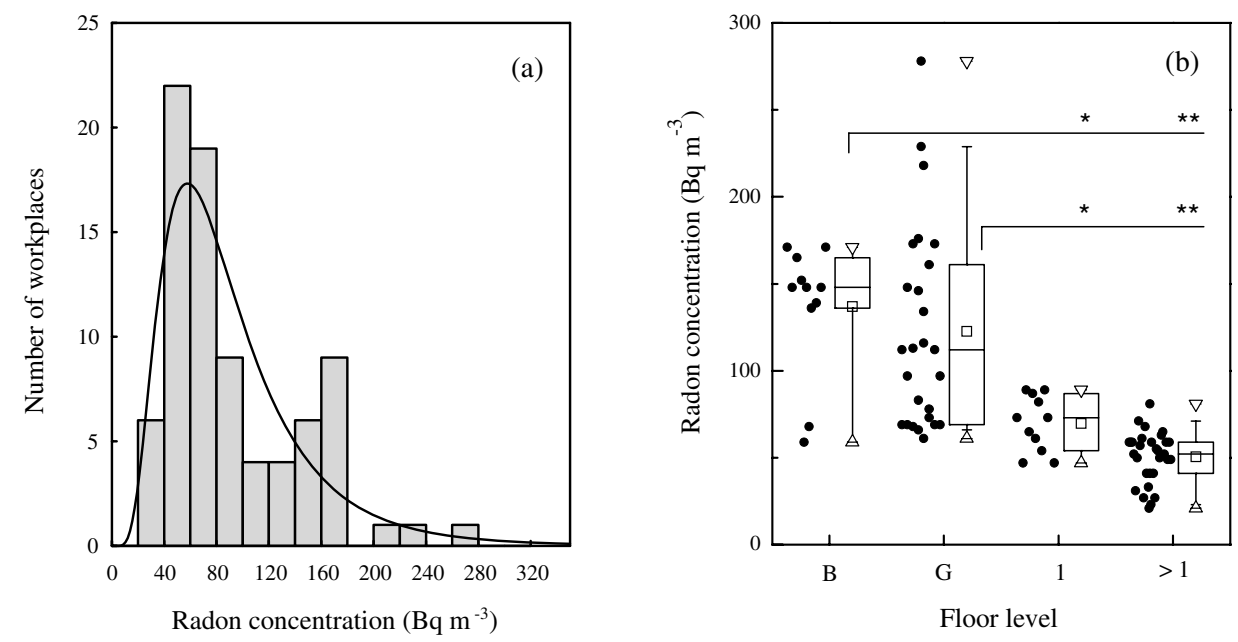

Figure 2. (a) Distribution of radon concentrations measured in workplaces. (b) Box-whisker plot of radon concentrations, broken down by floor level $(B=$ basement, $\mathrm{G}=$ ground floor, $1=$ first floor, $>1=$ above first floor). Boxes represent the lower-upper quartiles and median values, whiskers denote the 5-95\% range of the distribution and open squares stand for mean values. Statistically significant differences $(* \mathrm{p}<0.001 ; * * \mathrm{p}<$ $0.0001)$ between floors are also indicated.
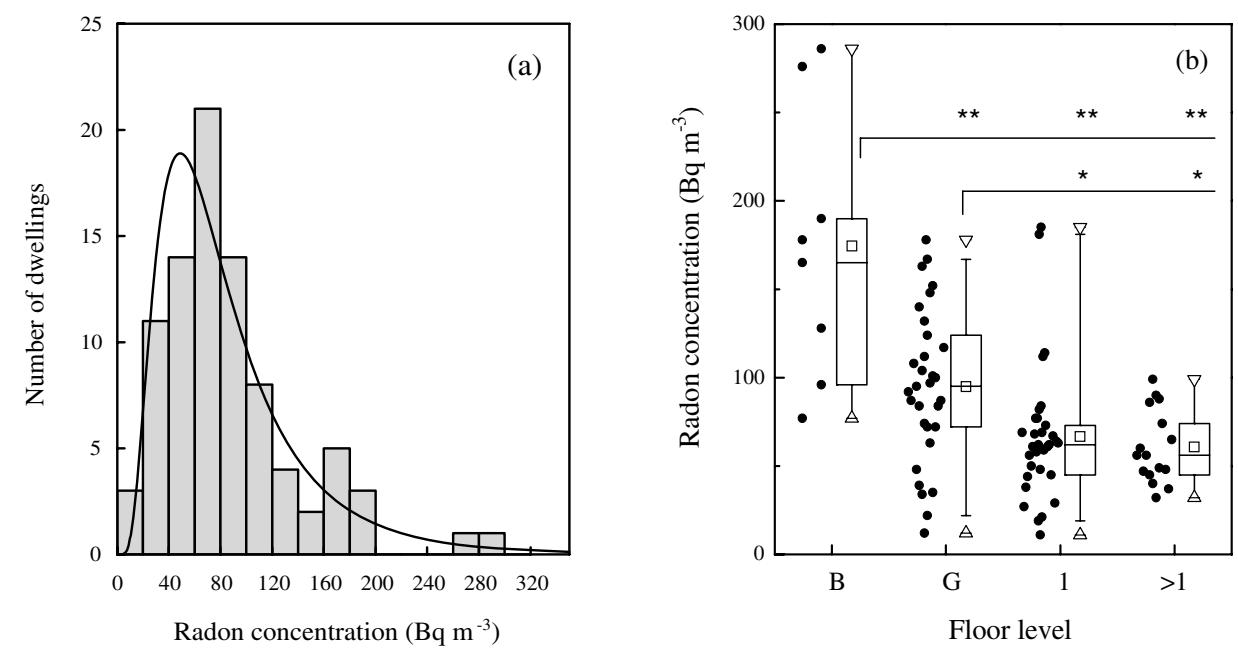

Figure 3. (a) Distribution of radon concentrations measured in dwellings. (b) Box-whisker plot of radon concentrations, broken down by floor level (refer to Fig. $2 \mathrm{~b}$ for symbol explanation).

radon. Concentrations were found to be log-normally distributed, ranging from 21 to $278 \mathrm{~Bq} \mathrm{~m}^{-3}$ in workplaces and from 11 to $286 \mathrm{~Bq} \mathrm{~m}^{-3}$ in dwellings. The study supports the recommendation of testing mainly ground floor and basement constructions, since radon concentrations were found to be significantly elevated compared to upper floors.

\section{Acknowledgments}

This work was partially supported by the Greek Secretariat of Research and Technology (Contract GSRT-174 $\gamma$ ). 


\section{References}

[1] D. Nikolopoulos, A. Louizi, V. Koukouliou, A. Serefoglou, E. Georgiou, K. Ntalles and Ch. Proukakis, J Environ Radioact 63, 173 (2002).

[2] A. Clouvas, S. Xanthos and M. Antonopoulos-Domis, Radiat Prot Dosimetry 124, 68 (2007).

[3] C.A. Papachristodoulou, K.G. Ioannides, K.C. Stamoulis, D.L. Patiris and S.B. Pavlides, Health Phys 86, 619 (2004).

[4] D.L. Patiris, K. Blekas and K.G. Ioannides, Nucl Instrum Meth B244, 392 (2006).

[5] EC (European Commission), Recommendations for the implementation of title VII of the European Basic Safety Standards Directive (BSS) concerning significant increase in exposure due to natural radiation sources. Radiation Protection Series 88 (European Commission, Luxembourg, 1997).

[6] UNSCEAR (United Nations Scientific Committee on the Effects of Atomic Radiation), Sources and effects of ionizing radiation. Report to General Assembly, with Scientific Annexes (United Nations, New York, 2000).

[7] ICRP (International Commission on Radiological Protection), Protection against Radon-222 at home and at work, ICRP Publication 65 (Pergamon Press, Oxford, 1994).

[8] EC (European Commission), Commission recommendation on the protection of the public against indoor exposure to radon (90/143/Euroatom) (Commission of the European Communities, Brussels, 1990).

[9] K.G. Ioannides, K.C. Stamoulis and C.A. Papachristodoulou, Health Phys 79, 697 (2000). 
